\title{
Effects of Exogenous Selenium on Physiological Characteristics of Salix babylonica under 2,4-Dinitrophenol Stress
}

\author{
Guilong Fu ${ }^{1,2}$, Xiaofeng Yang ${ }^{2,3}$, Kejie Han ${ }^{1,2}$, Huicheng Xie ${ }^{1,2 *}$ \\ ${ }^{1}$ Mountain Tai Forest Ecosystem Research Station of State Forestry and Grassland Administration \\ ${ }^{2}$ Forestry College of Shandong Agricultural University, Taian China, \\ ${ }^{3}$ College of Life Sciences, Beijing Normal University, Beijing, China
}

Received: 14 December 2020

Accepted: 15 May 2021

\begin{abstract}
To explore the potential of phytoremediation 2,4-dinitrophenol (2,4-DNP) by Salix babylonica, its physiological response to 2,4-DNP, and the effect of exogenous selenium (Se) addition on its physiological response were studied in hydroponics. The results indicate that an increasing concentration of 2,4-DNP decreased the plant net photosynthetic rate $\left(P_{n}\right)$, transpiration rate $\left(T_{r}\right)$, chlorophyll content and increased intercellular $\mathrm{CO}_{2}$ concentration $\left(C_{i}\right)$. Both concentrations of Se increased $P_{n}$ and chlorophyll content and reduced $C_{i}$. At low concentrations of 2,4-DNP, Se addition reduced POD and SOD activity, whereas at high concentrations its effect was reversed. In conclusion, the non-stomatal factor was the main reason for 2,4-DNP inhibiting the photosynthesis of S. babylonica. The tolerance of S. babylonica to 2,4-DNP was strong when 2,4-DNP concentration is between 10 and $20 \mathrm{mg} \mathrm{L}^{-1}$. Adding low concentration Se $\left(\leq 2 \mu \mathrm{mol} \cdot \mathrm{L}^{-1}\right)$ can promote the photosynthesis of $S$. babylonica and enhance its tolerance to 2,4-DNP pollution.
\end{abstract}

Keywords: 2,4-DNP stress, Exogenous Se, Photosynthesis, Salix babylonica

\section{Introduction}

2,4-DNP, as a new pollutant, is highly toxic and difficult to be biodegraded [1-5]. It is often used in explosives, pesticides, and other industries [5, 6], and those industries often discharge wastewater containing 2,4-DNP into the environment. It endangers plants, animals, microorganisms, and human health [4], so it is urgent to find an effective method to

*e-mail: xiehc@sdau.edu.cn purify 2,4-DNP wastewater. Physical, chemical, and bioremediation methods have been used to degrade 2,4DNP wastewater, but these methods are often costly [1-3, 5-7]. Phytoremediation is a kind of technology with great application prospects [8]. It is widely used in the remediation of polluted water and soil because of its strong remediation ability and low cost [9]. However, phytoremediation technology also has some disadvantages, such as a long time for plant growth and toxic stress to plant from pollutants. Therefore, it is necessary to add some exogenous substances to improve the tolerance of plants to pollutants in their growth cycle [8]. Selenium is an essential micronutrient for 
many organisms [10]. The regulation of Se level in an organism is of positive significance to its physiological activities. Deng et al. found that the concentration of selenium in crops could be effectively regulated by appropriately changing the Se source and time of selenium spraying on leaf surface [11]. Hasanuzzama et al. inferred that low concentration Se has a positive effect on crop growth and stress tolerance [12]. Cao et al. found that when plants are in an adverse environment, Se addition can improve the ability of plants to produce antioxidant substances [13]. Other studies have shown that $\mathrm{Se}$ can protect plants from heavy metal stress, salt stress, and so on [14-17]. Therefore, it may be used to improve the tolerance of plants to 2,4-DNP stress.

Salix babylonica is easy to reproduce and has strong adaptability and stress resistance [18]. It has great application value in the phytoremediation of polluted soil and water $[19,20]$. At present, it is mainly used for the remediation of heavy metal and cyanide pollution $[21,22]$. However, there is no report on the effect of $S$. babylonicaon used for remediation of 2,4-DNP in polluted water and the effect of Se addition on its tolerance to 2,4-DNP. In this study, the photosynthetic physiological response and enzyme activity of $S$. babylonica under different concentrations of 2,4-DNP solution stress and the effect of exogenous Se on the physiological response of $S$. babylonica to 2,4-DNP pollutants were studied through a water culture simulation experiment. This study aims to explore the tolerance of $S$. babylonica to 2,4-DNP pollution and whether the Se addition can improve its resistant ability to 2,4-DNP stress.

\section{Materials and Methods}

\section{Experimental Materials}

In early March, 2019, branches were cut from $S$. Babylonica trees in East Lake Park, Tai'an, Shandong, China. The branches were cut into $25 \mathrm{~cm}$ in length sections and then were placed into buckets filled with tap water. Those cuttings in buckets were cultured in a plastic greenhouse in the Forestry Experimental Station of Shandong Agricultural University $\left(117^{\circ} 20^{\prime} \mathrm{E}\right.$, $36^{\circ} 12^{\prime} \mathrm{N}$ ), Tai'an. When they had plentiful roots, each seedling was transplanted into one $500 \mathrm{~mL}$ conical beaker containing $400 \mathrm{~mL}$ half-strength Hoagland's hydroponic nutrient solution. Those conical beakers are covered by a black plastic film to deter algal growth.

\section{Experimental Design}

In the experiment, the healthy and similar growth status seedlings of $S$. babylonica were treated with Hoagland nutrient solution containing 2,4-DNP and Se. Se was spiked with $\mathrm{Na}_{2} \mathrm{SeO}_{3}$ as 3 concentrations: $0 \quad\left(\mathrm{Se}_{0}\right), 1 \quad\left(\mathrm{Se}_{1}\right)$ and $2\left(\mathrm{Se}_{2}\right) \mu \mathrm{mol} \cdot \mathrm{L}^{-1}$. 2,4-DNP were supplied at 4 levels: $0\left(2,4-\mathrm{DNP}_{0}\right), 10\left(2,4-\mathrm{DNP}_{10}\right)$,
$15\left(2,4-\mathrm{DNP}_{15}\right)$, and $20\left(2,4-\mathrm{DNP}_{20}\right) \mathrm{mg} \cdot \mathrm{L}-1$. There are 10 treatments in total. Those treatments are as follows: $\mathrm{Se}_{0}+2,4-\mathrm{DNP}_{0}$ (control), $\mathrm{Se}_{0}+2,4-\mathrm{DNP}_{10}, \mathrm{Se}_{0}+2,4-\mathrm{DNP}_{15}$, $\mathrm{Se}_{0}+2,4-\mathrm{DNP}_{20}, \mathrm{Se}_{1}+2,4-\mathrm{DNP}_{10}, \mathrm{Se}_{1}+2,4-\mathrm{DNP}_{15}, \mathrm{Se}_{1}+2,4-$ $\mathrm{DNP}_{20}, \mathrm{Se}_{2}+2,4-\mathrm{DNP}_{10}, \mathrm{Se}_{2}+2,4-\mathrm{DNP}_{15}, \mathrm{Se}_{2}+2,4-\mathrm{DNP}_{20}$. Each treatment has four replicates. After six days of stress, the physiological indexes were measured.

\section{Determination of Photosynthetic Parameters}

The photosynthetic parameters were measured by Li-6800 portable photosynthesis system (Li COR, USA). The net photosynthetic rate $\left(P_{n}, \mu \mathrm{mol} \cdot \mathrm{m}^{-2} \cdot \mathrm{s}^{-1}\right)$, transpiration rate $\left(T, \quad \mathrm{mmol} \cdot \mathrm{m}^{-2} \cdot \mathrm{s}^{-1}\right)$, intercellular $\mathrm{CO}_{2}$ concentration $\left(C_{i}, \mu \mathrm{mol} \cdot \mathrm{mol}^{-1}\right)$, and stomatal conductance $\left(G_{s}, \mathrm{mmol} \cdot \mathrm{m}^{-2} \cdot \mathrm{s}^{-1}\right)$ of mature leaves were measured in sunny weather. Three seedlings of each treatment were randomly selected for photosynthetic parameters determination and one upper mature leaf of each seedling was measured. Each leave was measured three times. The $\mathrm{CO}_{2}$ concentration was $400 \pm 10 \mu \mathrm{mol} \cdot \mathrm{mol}^{-1}$, the air temperature in the leaf chamber was set $25^{\circ} \mathrm{C}$, the relative humidity within the chamber was at $40-45 \%$ and photosynthetic active radiation was set at $500 \mu \mathrm{mol} \cdot \mathrm{m}^{-2} \cdot \mathrm{s}^{-1}$.

\section{Determination of Chlorophyll Content}

The chlorophyll content of each plant was determined by the UV-1600 ultraviolet spectrophotometer (MAPADA). Each plant was weighed with $0.2 \mathrm{~g}$ fresh leaves. The chlorophyll- $a$ concentration $\left(\mathrm{Chl}_{a}\left(\mathrm{mg} \cdot \mathrm{L}^{-1}\right)=\right.$ $\left.12.21 \times O D_{663}-2.81 \times O D_{646}\right)$, chlorophyll- $b$ concentration $\left(C h l_{b}\left(\mathrm{mg} \cdot \mathrm{L}^{-1}\right)=20.13 \times O D_{646}-5.03 \times O D_{663}\right)$ and total chlorophyll concentration $\left(\mathrm{Chl}_{a}+\mathrm{Chl}_{b}\right)\left(\mathrm{mg} \cdot \mathrm{L}^{-1}\right)$.

\section{Determination of Enzyme Activity}

The enzyme activity was determined according to the determination method of Wang et al. [23]. The absorbance changes of SOD and POD were measured by UV-VIS dual-beam ultraviolet spectrophotometer (SP-756P), and their activities were calculated.

\section{Data Analysis}

The data were processed and graphed by IBM SPSS Statistics 20.0 and Origin 2019. The difference among treatments was analyzed by one-way analysis of variance (ANOVA) with Duncan's multiple-range test at $\mathrm{P}<0.05$.

\section{Results and Discussion}

\section{Effects 2,4-DNP and Se on Photosynthetic Parameters of $S$. babylonica}

Photosynthesis is an important basis for plants to carry out normal life activities [24]. The decrease 

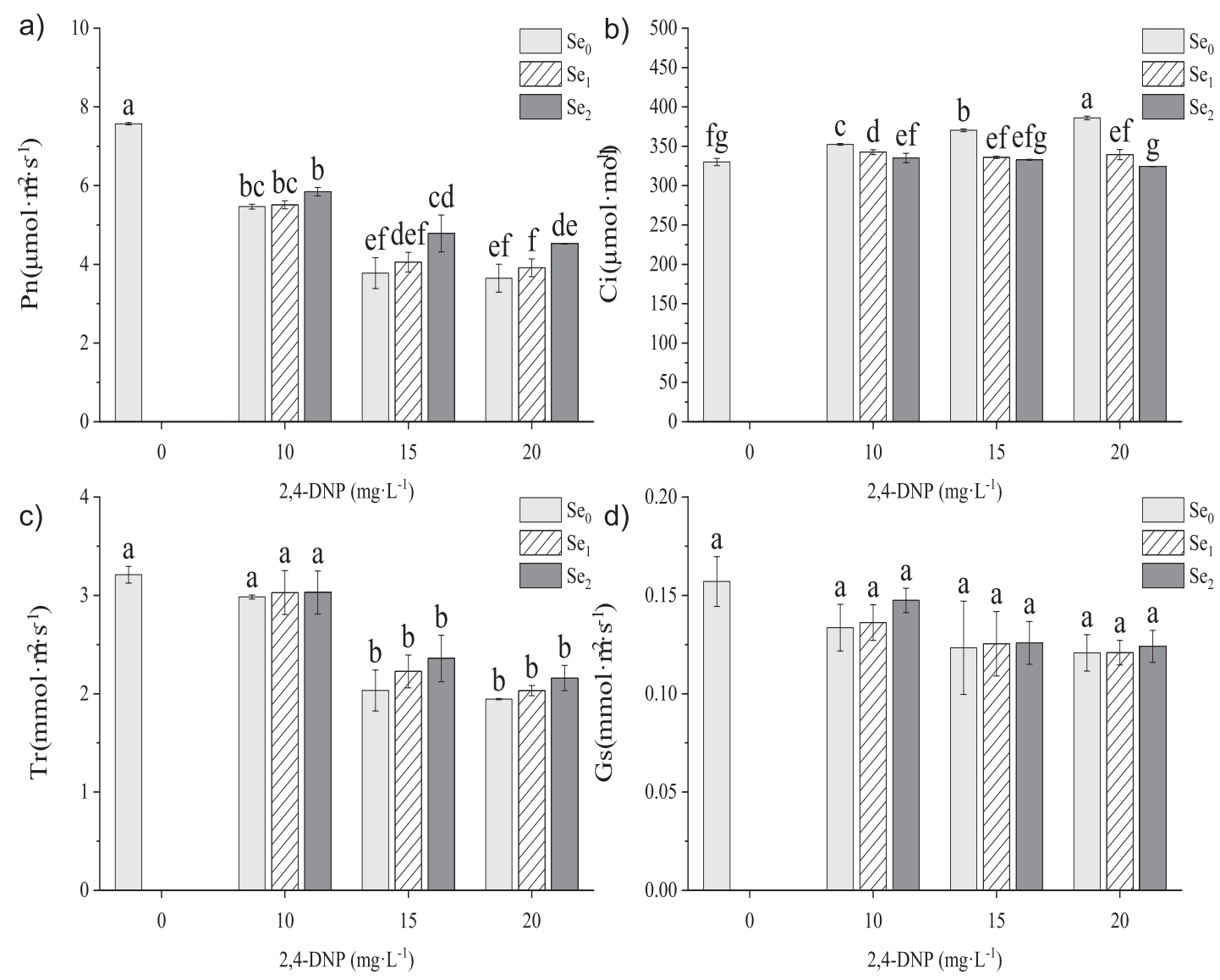

Fig. 1. Photosynthetic parameters of $S$. babylonica under 2,4-DNP stress and Se addition. Data are means \pm standard errors. Bars followed by different letters show significant differences at $P<0.05$.

of photosynthesis indicates that plant growth is inhibited by heavy metals or other factors [25-27]. In this experiment, the 2,4-DNP alone decreased the net photosynthetic rate $(P)$, transpiration rate $(T)$, and stomatal conductance $\left(G_{s}\right)$ of $S$. babylonica, whereas increased its intercellular $\mathrm{CO}_{2}$ concentration $\left(C_{i}\right)$ (Fig. 1). The $P_{n}, C_{i}$ and $T_{r}$ of $S$. babylonica. under different concentrations of 2,4-DNP stress showed significant differences $(\mathrm{P}<0.05)$ (Fig. 1(a-c)). Compared with only 2,4-DNP treatment, adding $\mathrm{Se}_{1}$ into 2,4-DNP solution increased $P_{n}$ by $0.79 \%, 6.84 \%$ and $6.69 \%$, and decreased $C_{i}$ by $2.77 \%, \quad 9.31 \%$ and $12.04 \%$ at 2,4-DNP ${ }_{10}, 2,4-\mathrm{DNP}_{15}$ and 2,4-DNP ${ }_{20}$, respectively, of $S$. babylonica. Adding $\mathrm{Se}_{2}$ into 2,4-DNP solution increased $P_{n}$ by $6.49 \%, 21.06 \%$ and $19.35 \%$, and decreased $C_{i}$ by $4.89 \%, 10.15 \%$ and $15.94 \%$ at $2,4-\mathrm{DNP}_{10}, 2,4-\mathrm{DNP}_{15}$ and 2,4-DNP 20 , respectively, of $S$. babylonica. After Se treatment, the $P_{n}$ and $T_{r}$ of $S$. babylonica increased, and the promotion effect of higher Se concentration was more significant than the lower Se concentration (Fig. 1(a-c)), which is similar to the study by Zhang et al. [31]. The melioration of photosynthesis in stressed plants by addition of Se maybe attribute to the decreased ROS levels, reactivation of antioxidants, restored structure of the damaged chloroplasts [32].

Some studies have shown that when plants are stressed by environmental factors, there is usually a transformation process from stomatal factors to non-stomatal factors in the decline of photosynthesis [28-30]. In this experiment, with the increase of 2,4-DNP concentration, the $P_{n}$ and $G_{s}$ of $S$. babylonica decreased, while the $C_{i}$ increased, indicating that the decline of photosynthesis was caused by nonstomatal factors. Moreover, it can be speculated from the experimental results that, when the concentration of 2,4-DNP is $0-10 \mathrm{mg} \cdot \mathrm{L}^{-1}$, there should be a critical 2,4-DNP concentration that changes from stomatal factor to non-stomatal factor during the decline of photosynthesis of $S$. babylonica, and its value should be further studied. Although the promotion effect of a higher concentration of $\mathrm{Se}$ on plants is more significant in this experiment, it is not that the higher the concentration of Se, the better the promotion effect of plants. High concentration Se is toxic to plants [33], so it is necessary to select the appropriate concentration when adding Se.

\section{Effect of 2,4-DNP and Se on Chlorophyll Content of $S$. babylonica}

Chlorophyll is an important photosynthetic pigment in plants, and its content is related to photosynthesis $[34,35]$. The chlorophyll content of $S$. babylonica decreased with the increase of 2,4-DNP concentration, 
indicating that the chloroplast structure of $S$. babylonica was damaged by 2,4-DNP stress (Fig. 2). In the concentration range of 2,4-DNP used in this experiment, adding $\mathrm{Se}_{1}$ and $\mathrm{Se}_{2}$ all improved the chlorophyll content. When the concentration of 2,4-DNP was $10 \mathrm{mg} \cdot \mathrm{L}^{-1}$, the application of $\mathrm{Se}_{1}$ and $\mathrm{Se}_{2}$ increased the total amount of chlorophyll-a and chlorophyll-b by $11.3 \%$ and $15.82 \%$, respectively. When the concentration of 2,4-DNP was $15 \mathrm{mg} \cdot \mathrm{L}^{-1}$, the application of $\mathrm{Se}_{1}$ and $\mathrm{Se}_{2}$ increased the total amount of chlorophyll- $a$ and chlorophyll- $b$ by $17.69 \%$ and $33.6 \%$, respectively. When the concentration of 2,4-DNP was $20 \mathrm{mg} \cdot \mathrm{L}^{-1}$, the application of $\mathrm{Se}_{1}$ and $\mathrm{Se}_{2}$ increased the total amount of chlorophyll- $a$ and chlorophyll- $b$ by $65.54 \%$ and $66.09 \%$, respectively. Under the stress of medium and low concentration of 2,4-DNP, adding $\mathrm{Se}_{2}$ had a more significant effect on chlorophyll content of $S$. babylonica than adding $\mathrm{Se}_{1}$, but the difference was not significant at higher concentration.

In this experiment, the chlorophyll content decreased with the increase of 2,4-DNP stress. It may be that 2,4DNP reduced the chlorophyll precursor, resulting in the inhibition of chlorophyll synthesis and photosynthesis. Under the stress of a high concentration of 2,4-DNP, the leaves of $S$. babylonica became yellow, and the growth potential was weaker than that of a low concentration of 2,4-DNP, which was consistent with the decrease of chlorophyll content and similar to the result obtained by Ibrahim et al. [36]. Their research found that under the stress of salt, the cotton chlorophyll concentration decreased. Iqbal et al. [37] and Malik et al. [38] suggest that appropriate concentrations of exogenous selenium may increase chlorophyll content and protect chloroplast structures from oxidative damage. Other studies have found that applying a certain concentration of selenium can increase the content of chlorophyll in maize, spinach, sorghum, and so on [39, 40, 48]. In this experiment, the content of chlorophyll did increase after adding Se (Fig. 2). The reason may be that the damage of chloroplast membrane structure caused by 2,4-DNP can be repaired after increasing Se, thus increasing the chlorophyll content. It is also possible that the application of selenium reduces the oxidative damage caused by hydrogen peroxide and increases chlorophyll content [41].

\section{Effect of 2,4-DNP and Se on the Enzyme Activity of S. babylonica}

Pollutant stress can increase the content of reactive oxygen species (ROS) in plants, and then trigger membrane lipid peroxidation, which forms oxidative stress on plants [42]. To prevent ROS damage, plants eliminate ROS through an enzyme antioxidant defense system to avoid oxidative stress damage [43]. SOD and POD are essential enzymes for scavenging ROS. The activity of SOD and POD can be used to infer the activity of the antioxidant system of enzymes
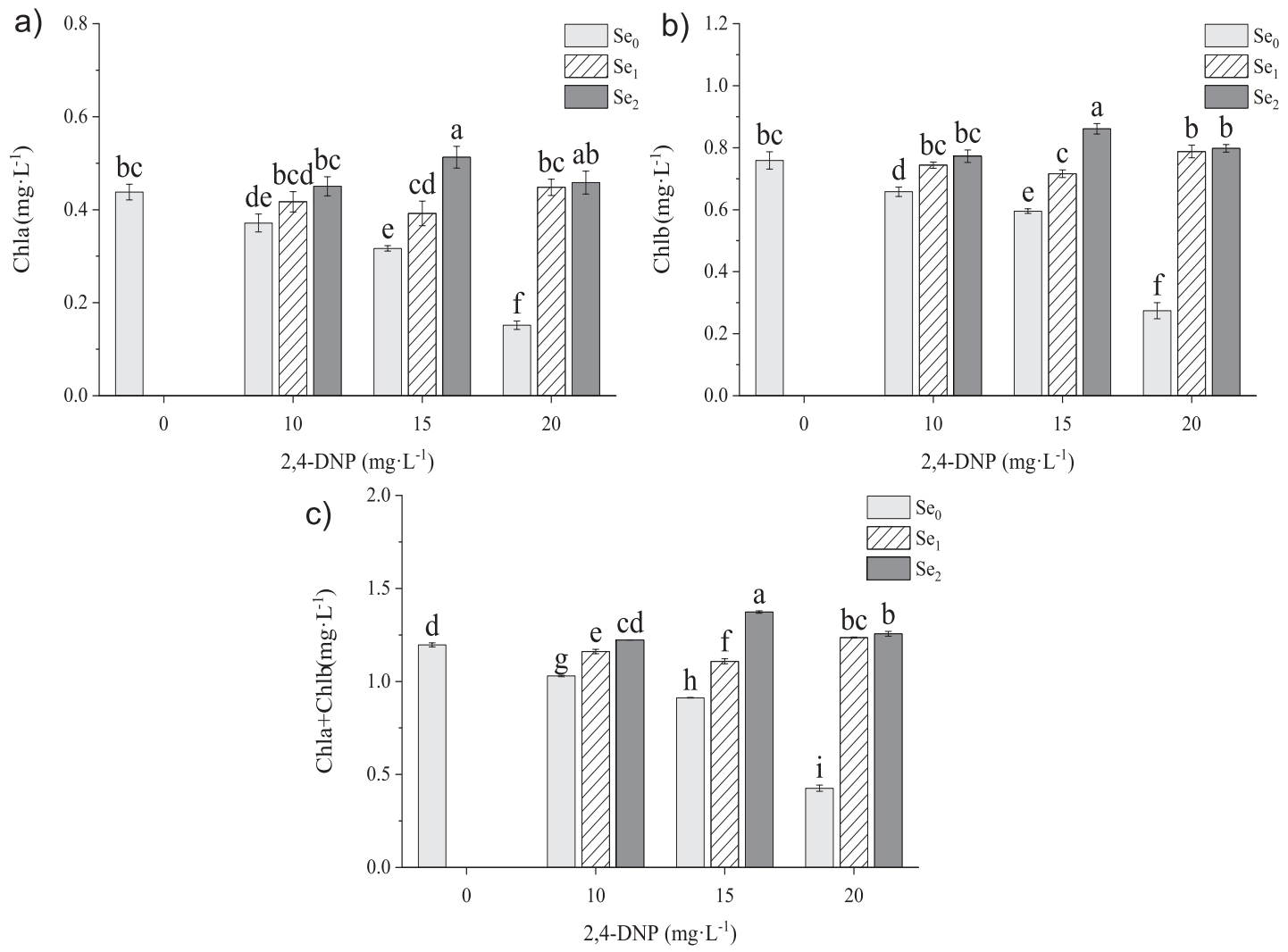

Fig. 2. Effect of Se on Chlorophyll content in seedlings of $S$. babylonica under 2,4-DNP stress. Data are means \pm standard errors. Bars followed by different letters show significant differences at $\mathrm{P}<0.05$. 

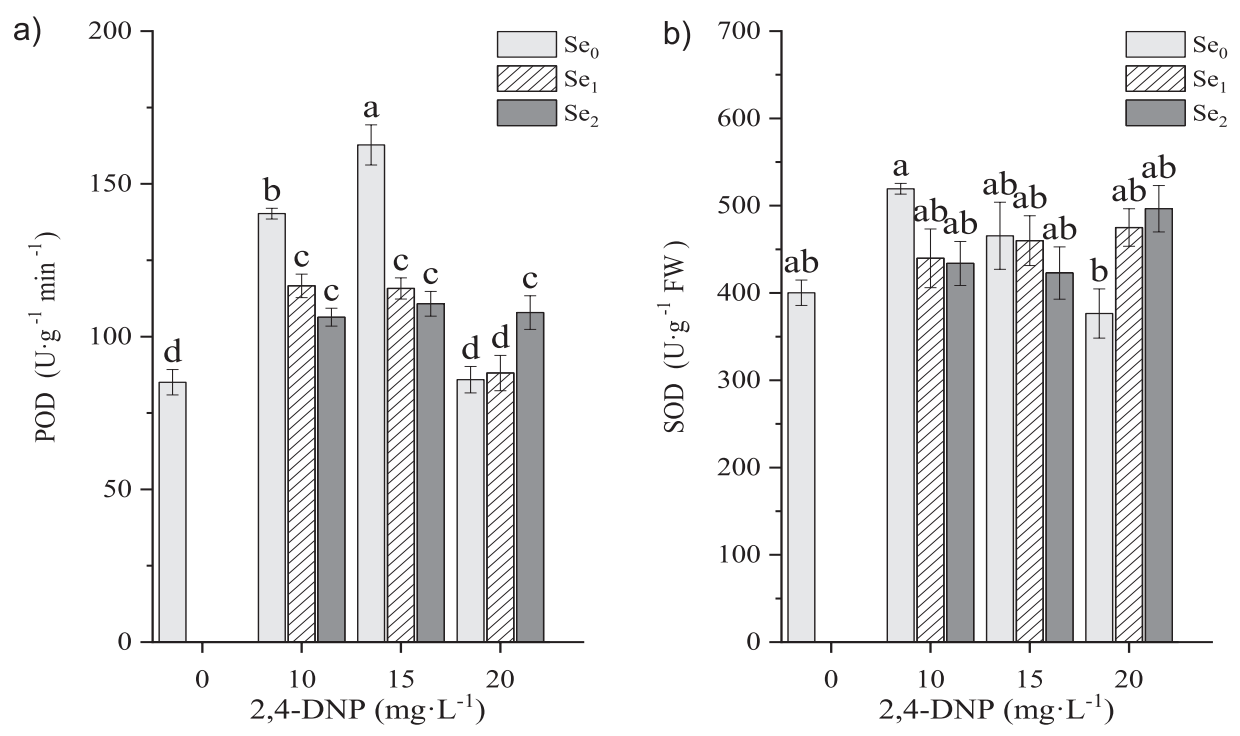

Fig. 3. Effect of Se on POD and SOD in 2,4-DNP induced S. babylonica seedlings. Data are means \pm standard errors. Bars followed by different letters show significant differences at $\mathrm{P}<0.05$.

in plants, and then reflect the protective ability of plants [44-46]. In the absence of $\mathrm{Se}$, with the increase of 2,4-DNP concentration, the activity of POD showed an increasing trend firstly, reaching the maximum value at the concentration of $15 \mathrm{mg} \cdot \mathrm{L}^{-1}$ and then decreasing (Fig. 3a). SOD also had the same trend, but reached the maximum value at the concentration of $10 \mathrm{mg} \cdot \mathrm{L}^{-1}$ and then decreased (Fig. 3b). After the addition of $\mathrm{Se}_{1}$, the POD and SOD activities decreased by $16.85 \%$ and $15.34 \%$ at $10 \mathrm{mg} \cdot \mathrm{L}^{-1}$, decreased by $28.88 \%$ and $1.21 \%$ at $15 \mathrm{mg} \cdot \mathrm{L}^{-1}$, and increased by $2.48 \%$ and $20.76 \%$ at $20 \mathrm{mg} \cdot \mathrm{L}^{-1}$, respectively. After adding $\mathrm{Se}_{2}$, the activities of POD and SOD decreased by $24.16 \%$ and $16.47 \%$ at $10 \mathrm{mg} \cdot \mathrm{L}^{-1}, 31.97 \%$ and $9.18 \%$ at $15 \mathrm{mg} \cdot \mathrm{L}^{-1}$, and increased by $20.38 \%$ and $24.19 \%$ at $20 \mathrm{mg} \cdot \mathrm{L}^{-1}$

In this experiment, the activities of POD and SOD increased first and then decreased with the increase of 2,4-DNP concentration (Fig. 1). POD reached the highest when 2,4-DNP concentration was $15 \mathrm{mg} \cdot \mathrm{L}^{-1}$, while SOD was the highest when 2,4-DNP concentration was $10 \mathrm{mg} \cdot \mathrm{L}^{-1}$, which indicated that $S$. babylonica could effectively activate the enzyme antioxidant defense system at a low concentration of 2,4-DNP stress and reduce the damage of oxidative stress on itself. However, this enzyme defense system is not indestructible. Excessive concentration of pollutants will produce excessive $\mathrm{H}_{2} \mathrm{O}_{2}$, which may lead to the reduction of plant cell wall elongation, and eventually terminate plant growth rapidly and damage the enzyme system [46]. After Se application, the activities of the two enzymes decreased at low 2,4DNP concentration. This may be because Se quenched the ROS to low level, the SOD activity was partially activated [48-51]. At $20 \mathrm{mg} \cdot \mathrm{L}^{-1}$ 2,4-DNP, the increase of Se promoted the activities of the two enzymes (Fig. 1). It was speculated that under a severe stress, high levels of $\operatorname{ROS}\left(\mathrm{O}_{2} \bullet^{-}\right)$will be produced, and SOD activity was activated [32].

\section{Conclusion}

2,4-DNP could inhibit the growth of S. babylonica, and the main reason for the reduction of photosynthesis was non-stomatal factors. $S$. babylonica could endured well 2,4-DNP in concentration (20 $\mathrm{mg} \cdot \mathrm{L}^{-1}$ and below) used in this study. The addition of low concentration Se ( $2 \mu \mathrm{mol} \cdot \mathrm{L}^{-1}$ or below) could promote the photosynthesis of $S$. babylonica to a certain extent by repairing the chloroplast and membrane system and enhance the tolerance of S. babylonica to 2,4-DNP.

\section{Abbreviations}

$T_{r}$, transpiration rate; $G_{s}$, stomatal conductance; $C_{i}$, intercellular $\mathrm{CO}_{2}$ concentration; $\mathrm{P}_{n}$, net photosynthetic rate; 2,4-DNP,2,4-dinitrophenol; Se, selenium; $S$. babylonica, Salix babylonica.

\section{Acknowledgements}

This research was financially supported by the Natural Science Foundation of Shandong Province as 'The mechanism of purifying dye-containing wastewater by phytoremediation' (Approved No.ZR2015CM021).

\section{Conflict of Interest}

The authors declare no conflict of interest. 


\section{References}

1. SHUKLA S.S., DORRISA K.L., CHIKKAVEERAIAH B.V. Photocatalytic degradation of 2,4-dinitrophenol. Journal of Hazardous Materials, 164, 310, 2009.

2. CAO X.Y., ODA Y., SHIRAISHI F. Photocatalytic and adsorptive treatment of 2,4-dinitrophenol using a $\mathrm{TiO}_{2}$ film covering activated carbon surface. Chemical Engineering Journal, 156 (1), 98, 2010.

3. SRINIVASAN K., STALIN T., SIVAKUMAR K. Spectral and electrochemical study of host-guest inclusion complex between 2,4-dinitrophenol and $\beta$-cyclodextrin. Spectrochimica Acta. Part A, Molecular and Biomolecular Spectroscopy, 94, 89, 2012.

4. THANG P.Q., JITAE K., GIANG B.L., VIET N.M., HUONG P.T. Potential application of chicken manure biochar towards toxic phenol and 2,4-dinitrophenol in wastewaters. Journal of Environmental Management, 251, 109556, 2019.

5. RAHMANI H., LAKZIAN A., KARIMI A., HALAJNIA A. Efficient removal of 2,4-dinitrophenol from synthetic wastewater and contaminated soil samples using free and immobilized laccases. Journal of Environmental Management, 256, 109740, 2020.

6. DEHGHANIFARD E., JAFARI A.J., KALANTARY R.R., MAHVI A.H., FARAMARZIM.A., ESRAFILI A. Biodegradation of 2,4-dinitrophenol with laccase immobilized on nano-porous silica beads. Iranian Journal of Environmental Health Science \& Engineering, 10 (1), $25,2013$.

7. TANG T., YUE Z., WANG J., CHEN T. H., QING C. S. Goethite promoted biodegradation of 2,4-dinitrophenol under nitrate reduction condition. Journal of Hazardous Materials, 343, 176, 2018.

8. GERHARDT K.E., GERWING P.D., GREENBERG B.M. Opinion: Taking phytoremediation from proven technology to accepted practice. Plant Science, 256, 170, 2017.

9. BURGES A., EPELDE L., BLANCO F.J.M., BLANCO J.M., BECERRIL C. Ecosystem services and plant physiological status during endophyte-assisted phytoremediation of metal contaminated soil. Science of the Total Environment, 584-585, 329, 2017.

10. ZHU Y.G., SMITS E.A.H.P., ZHAO F.J., WILLIAMS P.N., MEHARG A.A. Selenium in higher plants: understanding mechanisms for biofortification and phytoremediation. Trends in Plant Science, 14 (8), 436, 2009.

11. DENG X.F., LIU K.Z., LI M.F., ZHANG W., ZHAO X.H., ZHAO Z.Q., LIU X.W. Difference of selenium uptake and distribution in the plant and selenium form in the grains of rice with foliar spray of selenite or selenate at different stages. Field Crops Research, 211, 165, 2017.

12. HASANUZZAMAN M., HOSSAIN M.A., FUJITA M. Selenium in higher plants: physiological role, antioxidant metabolism and abiotic stress tolerance[J]. Journal of Plant Sciences, 5 (4), 354, 2010.

13. CAO K., QIN Y.Z., GAO Q.X., WANG H.Y., SONG Y., HE C.Z. Research progress on the effects of selenium on cold resistance of plants under low-temperature stress. Chinese Agricultural Science Bulletin, 30 (11), 200, 2014.

14. KONG L., WANG M., BI D. Selenium modulates the activities of antioxidant enzymes, osmotic homeostasis and promotes the growth of sorrel seedlings under salt stress. Plant Growth Regulation, 45, 155, 2005.
15. FILEK M., GZYL-MALCHER B., ZEMBALA M. BEDNARSKA E., LAGGNER P., KRIECHBAUM M. Effect of selenium on characteristics of rape chloroplasts modified by cadmium. Journal of Plant Physiology, 167, 28, 2010.

16. ZHAO Y.Y., HU C.X., WANG X., QING X.J., WANG P., ZHANG Y., ZHANG X., ZHAO X.H. Selenium alleviated chromium stress in Chinese cabbage ( Brassica campestris L. ssp. Pekinensis) by regulating root morphology and metal element uptake. Ecotoxicology and Environmental Safety, 173, 314, 2019.

17. SUN H.Y., DAI H.X., WANG X.Y., WANG G.H. Physiological and proteomic analysis of selenium-mediated tolerance to $\mathrm{Cd}$ stress in cucumber (Cucumis sativus L.) [J]. Ecotoxicology and Environmental Safety, 133, 114126, 2016

18. YANG W.D., DING Z.L., ZHAO F.L., WANG Y.Y., ZHANG X.C., ZHU Z.Q., YANG X.E. Comparison of manganese tolerance and accumulation among 24 Salix clones in a hydroponic experiment: Application for phytoremediation. Journal of Geochemical Exploration, 149, 1, 2015.

19. CHEN G.C., LIU Z.K., ZHANG J.F., OWENS G. Phytoaccumulation of copper in willow seedlings under different hydrological regimes. Ecological Engineering, 44, 285, 2012

20. ALAHABADI A., EHRAMPOUSH M.H., MIRI M., AVAL H.E., YOUSEFZADEH S., GHAFFARI H.R., AHMADI E., TALEBI P., FATHABADI Z.A., BABAI F., NIKOONAHAD A., SHARAFI K., HOSSEINIBANDEGHARAEI A. A comparative study on capability of different tree species in accumulating heavy metals from soil and ambient air. Chemosphere,172, 459, 2017.

21. ZHANG F.Z., YU X.Z., GU J.D. Transport and assimilation of ferricyanide by three willow species. Water Air Soil Pollut, 224, 1522, 2013.

22. XUE W.X., SHANG X.S., JIANG Y., ZOU J. H.The effect of lead stress on the growth and photosynthetic physiological characteristics of Salix babylonica L. Journal of Tianjin Normal University, 40 (3), 28, 2020.

23. WANG Y.J., YANG J.S., YUAN C.P., LIU J.G., LI D.H., DONG S.T. Leaf senescence and antioxidant enzyme characteristics in different parts of Super High Yield Summer Corn at flowering and grain stage. Acta Agronomica Sinica, 39 (12), 2183, 2013.

24. LIU J., HOU H., ZHAO L., SUN Z.J., LI H. Protective Effect of foliar application of sulfur on photosynthesis and antioxidative defense system of rice under the stress of Cd. Science of the Total Environment, 710, 136230, 2020.

25. XIE H.C., LI C.R., LI J.H., WANG L. Phytoremediatgion of wastewater containing azo dye by sunflowers and their photosynthetic response. Acta Ecologica Sinica, 32 (5), 240, 2012

26. ZHANG Z.G., SHANG Q.M. Photosynthetic characteristics of pepper leaves under low temperature, low light and salt stress. Scientia Agricultura Sinica, 43 (1), 123, 2010.

27. PEI B., ZHANG G.C., ZHANG S.Y., WU Q., XU Z.Q., XU P. Effects of soil drought stress on photosynthetic characteristics and antioxidant enzyme activities in Hippophae rhamnoides Linn. seedings. Acta Ecologica Sinica, 33 (5), 1386, 2013.

28. QIAN Y.Q., ZHOU X.X., HAN L., SUN Z.Y., JU G.S. Rapid light-response curves of PSII chlorophyll fluorescence parameters in leaves of Salix leucopithecia 
subjected to cadmium- ion stress. Acta Ecologica Sinica, 31 (20), 6134, 2011.

29. WANG L., YANG H.Q., FAN W.G., ZHANG Z. Effect of $\mathrm{CdCl}_{2}$ treatment on photosynthetic rate and chlorophyll fluorescence parameters in Malus hupehensis leaves. Scientia Agricultura Sinica, 43, 3176, 2010.

30. LI H., ZHANG G.C., XIE H.C., XU J.W., LI C.R., SUN J.W. The effect of phenol concentration on photosynthetic physiological parameters of Salix babylonica. Chinese Bulletin of Botany, 51 (1), 31, 2016.

31. ZHANG M., TANG S.H., HUANG X., ZHANG F.B., PANG Y.W., HUANG Q.Y., YI Q. Selenium uptake, dynamic changes in selenium content and its influence on photosynthesis and chlorophyll fluorescence in rice (Oryza sativa L.). Environmental and Experimental Botany, 107, 39, 2014.

32. FENG R.W., WEI C.Y. TU S.X. The roles of selenium in protecting plants against abiotic stresses. Environmental and Experimental Botany, 87, 58, 2013.

33. MAGDALENA M.Z., JOANNA S., AGNIESZKA H. Selenium improves physiological parameters and alleviates oxidative stress in shoots of lead-exposed Vicia faba L. minor plants grown under phosphorus-deficient conditions. Plant Growth Regul, 36, 186, 2017.

34. TANG Y.P., SUN X., WEN T., LIU M.J., YANG M.Y., CHEN X.F. Implications of terminal oxidase function in regulation of salicylic acid on soybean seedling photosynthetic performance under water stress. Plant Physiology and Biochemistry, 112, 19, 2017.

35. WANG X., ZHOU S.B., CHENG L.L., WU X.Y. Response of rice and weedy rice subjected to cadmium stress: a comparative study[J]. Journal of Agro-Environment Science, 31 (4), 661, 2012.

36. IBRAHIM W., AHMED I.M., CHEN X.H., WU F.B. Genotype-dependent alleviation effects of exogenous GSH on salinity stress in cotton is related to improvement in chlorophyll content, photosynthetic performance, and leaf/ root ultrastructure. Environ Sci Pollut Res, 24, 9417, 2017.

37. IQBAL M., HUSSAIN I., LIAQAT H., ASHRAF M. A., RASHEED R., REHMAN A.U. Exogenously applied selenium reduces oxidative stress and induces heat tolerance in spring wheat. Plant physiology and biochemistry: PPB, 94, 96, 2015.

38. MALIK J.A., GOEL S., KAUR N., SHARMA S., SINGH I., NAYYAR H. Selenium antagonises the toxic effects of arsenic on mungbean (Phaseolus aureus Roxb.) plants by restricting its uptake and enhancing the antioxidative and detoxification mechanisms. Environ. Exp. Bot, 77, 242, 2012.

39. NAWAZ F., NAEEM M., ASHRAF M.Y., TAHIR M.N., ZULFIQAR B., SALAHUDDIN M., SHABBIR R.N., ASLAM M. Selenium supplementation affects physiological and biochemical processes to improve fodder yield and quality of maize (Zea mays L.) underwater deficit conditions. Front. Plant Sci., 7, 1438, 2016.

40. SAFFARYAZDI A., LAHOUTI M., GANJEALI A., BAYAT H. Impact of selenium supplementation on growth and selenium accumulation on spinach (Spinacia oleracea L.) plants. Not. Sci. Biol., 4 (4), 95, 2012.

41. ASHRAF M.A., AKBAR A., PARVEEN A., RASHEED R., HUSSAIN I., IQBAL M. Phenological application of selenium differentially improves growth, oxidative defense and ion homeostasis in maize under salinity stress. Plant Physiology and Biochemistry, 123, 268, 2018.

42. LOTFI R., PESSARAKLI M., GHARAVIKOUCHEBAGH P., KHOSHVAGHTI H. Physiological responses of Brassica napus to fulvic acid under water stress: chlorophyll a fluorescence and antioxidant enzyme activity. The Crop Journal, 5, 434, 2015.

43. KUMAR M., BIJO A.J., BAGHEL R.S., REDDY C.R.K., JHA B. Selenium and spermine alleviate cadmium induced toxicity in the red seaweed Gracilaria dura by regulating antioxidants and DNA methylation. Plant Physiology and Biochemistry, 51, 129, 2012.

44. FENG R.W., LIAO G.J., GUO J.K., WANG R.G., XU Y.M., DING Y.Z., MO L.Y., FAN Z.L., LI N.Y. Responses of root growth and antioxidative systems of paddy rice exposed to antimony and selenium. Environmental and Experimental Botany, 122, 29, 2016.

45. NAWAZ F., AHMAD R., ASHRAF M.Y., WARAICH E.A., KHAN S.Z. Effect of selenium foliar spray on physiological and biochemical processes and chemical constituents of wheat under drought stress. Ecotoxicology and environmental safety, 113, 191, 2015.

46. DING Y.Z., WANG Y.J., ZHENG X.Q., CHENG W.M., SHI R.G., FENG R.W. Effects of foliar dressing of selenite and silicate alone or combined with different soil ameliorants on the accumulation of $\mathrm{As}$ and $\mathrm{Cd}$ and antioxidant system in Brassica campestris $[\mathrm{J}]$. Ecotoxicology and Environmental Safety, 142, 207, 2017.

47. SCHUTZENDUBEL A., POLLE A. Plant responses to abiotic stresses: heavy metal-induced oxidative stress and protection by mycorrhization. Journal of Experimental Botany, 53 (372), 1351, 2002.

48. DJANAGUIRAMAN M., PRASAD P.V.V., SEPPANEN M. Selenium protects sorghum leaves from oxidative damage under high temperature stress by enhancing antioxidant defense system. Plant Physiology and Biochemistry, 48, 999, 2010.

49. XU D.N., LI W.Y., HUANG Y.M., HE J.H., TIAN Y.B. The effect of selenium and Polysaccharide of Atractylodes Macrocephala Koidz. (PAMK) on immune response in chicken spleen under heat stress. Biol Trace Elem Res, 160, 232, 2014

50. ARDEBILI N.O., SAADATMAND S., NIKNAM V., KHAVARI-NEJAD R.A. The alleviating effects of selenium and salicylic acid in salinity exposed soybean[J]. Acta Physiol Plant, 36, 3199, 2014.

51. QING X.J., ZHAO X.H., HU C.X., WANG P., ZHANG Y., ZHANG X., WANG P.C., SHI H.Z., JIA F., QU C.J. Selenium alleviates chromium toxicity by preventing oxidative stress in cabbage (Brassica campestris L. ssp. Pekinensis) leaves. Ecotoxicology and environmental safety, 114, 179, 2015. 